Article

\title{
The New Visibility of Religion and Its Impact on Populist Politics
}

\section{Michael Hoelzl}

Department of Religions and Theology, Faculty of Humanities, School of Arts, Languages and Cultures, The University of Manchester, Manchester M13 9PL, UK; Michael.Hoelzl@manchester.ac.uk

Received: 28 April 2020; Accepted: 11 June 2020; Published: 15 June 2020

\begin{abstract}
The marginalised research field of populism and religion has mainly focused on the positive aspects of how religion and populism can be combined with mutual benefits for both parties, whereas the critical potential and limitations that religion and theology pose to populist politics has often been overlooked. The following essay intends to contribute to the complex research area of religion and populism, by focusing on the negative side, that is, the incompatibilities of religion and theology with populism. It is suggested that the very nature of religious belief and theological convictions impose limits on their use in populist politics.
\end{abstract}

Keywords: populism; religion; resentment; secularisation; theology

\section{Introduction}

The following essay on religion and populist politics is based on a puzzling observation. Why do populist leaders seldomly refer to religion in their public speeches, despite the enormous power religion could provide for their populist course? It seems that, despite the frequent and vague borrowings from religion by modern populist leaders, explicit references to theological doctrines are avoided. This is surprising if, according to the new visibility of religion thesis, religion has re-entered the public sphere in various new forms after a period of its assumed disappearance that was predicted by sociologists of secularisation. The new visibility of religion today allows politics, and populist politics in particular, to utilise religion as a tool to achieve political ends. Religion is often treated with caution by populist leaders and populist movements. Why?

So far, the marginalised research field of populism and religion has mainly focused on the positive aspects of how religion and populism can be combined with mutual benefits for both parties. Moreover, there is no doubt that religion, theological metaphors and allusions to a commonly assumed religiously inspired imagination of a people's cultural identity (Marzouki et al. 2016) can be, and has been, utilized by populist movements. ${ }^{1}$ On the other hand, one has to ask, what is the critical potential, and are there limitations that religion and theology pose to populist politics. This negative aspect of religion and populist politics, I wish to argue, has often been overlooked.

Therefore, the following essay intends to contribute to the complex research area of religion and populism by focusing on the negative side, that is, the incompatibilities of religion and theology with populism. It is suggested that the very nature of religious belief and theological convictions impose limits on their use in populist politics.

Preluded by an evaluation of the study of religion and politics in contemporary research literature and followed by a diachronic analysis of the study of populist politics after the Second World War,

1 Oliver Roy stresses the importance of religion and Christianity in particular, for an exclusivist and xenophobic, predominantly Islamophobic construction of identity in right-wing populist politics (Marzouki et al. 2016, pp. 5, 79). 
three limitations posed by religious belief and theological convictions to populism will be suggested. The first limitation is based on the sociological findings regarding secularisation and its implied pluralisation of religious belief, which is detrimental to the populist appeal to a religiously unified people. The second political-philosophical argument focuses on the incompatibility of theological notions of a transcendent sovereign authority, with an immanent political understanding of sovereign authority. Finally, from a normative perspective, it will be argued that universal salvation religion's moral teachings on charity cannot be reconciled with any forms of resentment and the friend/enemy dichotomy on which populist politics relies.

\section{The Study of Religion and Populism}

The sparse references to religion and vague, more or less superficial, allusions to theological themes in populist politics are the focus of the present study. As mentioned above, the study of religion and populism is, in itself, a frequently ignored area in the study of populism and has only very recently been studied in greater detail by social scientists (e.g., Marzouki et al. 2016; Guth 2016; Whitehead and Perry 2020). Jose Pedro Zúquete, in the Oxford Handbook of Populism, confirms the neglect of religion and populism as a research area when he states: 'The study of the relationship between populism and religion has for a long time remained a neglected area of social-scientific research' (Zúquete 2017, p. 445). He then continues to give an overview of this 'neglected area of research' by focusing on the phenomenon of religious populism. Religious populism is dialectically understood as a 'politicization of religion' on the one hand, and a 'sacralization of politics in modern day societies', on the other (Zúquete 2017, p. 445).

The marginalisation and neglect of religion in the study of populist politics is even more surprising, if populism is broadly conceived as a 'moralistic imagination of politics'. According to Jan-Werner Müller:

Populism [ ... ] is a particular moralistic imagination of politics, a way of perceiving the political world which places in opposition a morally pure and fully unified people against small minorities, elites in particular, who are placed outside the authentic people.

(Müller 2015, p. 83)

To theologically trained ears, Müller's definition of populism as a moralistic imagination of politics in which a pure and unified authentic people is set against an elitist, immoral minority is reminiscent of Augustine's dilemma outlined in his City of God and the early church's struggle with Gnosticism. Moreover, the strong Manichean dualism inherent in Augustine has been forcefully employed throughout the history of Western politics. Theological definitions of orthodoxy and heresy between the faithful and the apostate, the struggle of God's chosen people with its pagan environment have shaped politics even beyond the rise of Christianity, and are still present in populist politics of modern democratic culture. Religion has been, and still is, one of the most effective means to distinguish between the 'we' and the 'other', and can fruitfully be exploited by populists to construct an exclusivist identity politics (Marzouki et al. 2016). It is this clear that this distinction between ' $u s^{\prime}$ and 'them' undergirds Müller's definition of the populist moralistic imagination of politics (Zúquete 2017, p. 458).

Of course, the use of religious symbols and theological ideas, even in a disguised form, has been recognised by political philosophers and social scientists (Marzouki et al. 2016). Zúquete notes, on the study of religious populism and political religions:

References to the "quasi-religious imagery," "semi-religious overtones," or "almost religious significance" of populist politics—in which "the political becomes moral, even religious"—are recurrent in the description of populist movements [ ... ] Similarly, the use of religious language, at least in a fair number of empirical cases, has not gone unnoticed in the analysis of populisms. 
Zúquete's approach to the study of religious populism, the politicization of religion, the sacralization of politics, political theology and political religions in general, is based on the assumption of a tentatively positive use of religion in populist politics today. The other approach, which is followed in this essay, is to examine and to understand what restrictions to populist politics are imposed by religion and theology. What makes the reference to religion, religious symbols and theological ideas unsuitable to be fully embraced by populist leaders? In short: What is toxic about the use of religion in populist politics?

A look at the negative, toxic aspects of religion for populist politics is needed to complement the positive approach. Most studies in religion and populism rely on a discursive analysis of the positive use of quasi-religious motifs in populist politics and populist leaders' public performances. Such studies are illuminating and interesting. They constitute a field of research in their own right. However, following Zúquete's judgement, such an analysis is not enough. There must be 'something more' to investigate, because other styles of politics make use of the religious imagination and borrow from theological visions of salvation or a nation's destiny and the unity of the people. The success of populism in its use of 'religious vocabulary or imagery' (Zúquete 2017, p. 453) demands further attention.

Moreover, one can argue that the study of religion and populism needs to be moved to another level of investigation which transcends empirically based discourse analysis (Lesch 2017) ${ }^{2}$. Such a proposed development of the methodology applied to the study of religion and populism would also include the study of the non-discursive elements in the use of religion in populist politics. By non-discursive elements, I mean the public display of symbols, quasi-liturgical performances of populist politics, or body language in the performance of populist speeches, for example (Hoelzl 2020). Even if the non-discursive aspects of religion in populist politics are considered, the question why populist leaders seem to be cautious in their references to religion and allusions to theological themes remains.

Let's take, for example, Donald Trump's inaugural address to illustrate the ambiguity of populists' reference to religion. Trump's inaugural address is widely recognised as an almost perfect textbook example of populist politics today. The entire speech revolves around Trump's slogan 'Make America great again'. He speaks of a time of renewal of the American nation and its true, authentic people. Apart from the mandatory formula 'God bless America' to end this specific type of a publicly performed political address, religion is referred to only once, but in an intriguing context. About halfway through the speech, Trump says:

We will reinforce old alliances and form new ones-and unite the civilized world against Radical Islamic Terrorism, which we will eradicate completely from the face of the Earth. At the bedrock of our politics will be a total allegiance to the United States of America, and through our loyalty to our country, we will rediscover our loyalty to each other. When you open your heart to patriotism, there is no room for prejudice. The Bible tells us, "how good and pleasant it is when God's people live together in unity".

(Trump 2017)

This new born nation is then set up and defined against a commonly acknowledged enemy which needs to be eradicated entirely by all means: radical Islamic terrorism. ${ }^{3}$ The next sentence appeals to the solidarity among the true people, whose unity is defined against the commonly accepted enemy. In an inward-looking moment, the allegiance and solidarity of the people is conjured by the loyalty to the nation and patriotism, as an overarching moral duty of every true, morally pure and authentic

2 For an evangelical perspective on populism and religion, see the US-based research project on the topic of evangelicalism and national populism at Calvin University (n.d.): "Populists or Internationalists? Evangelical Responses to Globalization" https://calvin.edu/centers-institutes/henry-institute/projects/populists-or-internationalists/, last accessed May 2020. The most ambitious and comprehensive empirical study on populism in the Western world has been undertaken by (Norris and Inglehart 2019).

3 For a detailed discussion of Islamophobia, see (Marzouki et al. 2016). 
citizen. In the following two sentences, an interesting move towards religion is made. The opening of hearts, a profound religious phrase, is related to patriotism rather than to God. Patriotism, as it is promised, overcomes prejudges, and the appeal to the moral conscience of each true Christian is supported by the concluding quote of the biblical verse: 'how good and pleasant it is when God's people live together in unity'.

In Trump's inaugural address, it is assumed that the Bible is regarded as the ultimate source for moral guidance for everyone. The Bible is seen as the highest moral authority by every true, patriotic and genuine American. Hence, he can say without any exegetical sophistication: 'The Bible tells us ... ' and he continues to cite the opening line of Ps 133. Secondly, the context of Ps 133 and the concluding verse 3 of that Psalm: 'It is if as the dew of Hermon were falling on Mount Zion. For there the Lord bestows his blessings, even life forevermore', could be interpreted as a commitment to (Christian) Zionism and implicit territorial claims. ${ }^{4}$ In combination with Trump's promise to fight Islamic Terrorism at the beginning of the passage of the address, a subtle political message is sent out. In fact, the reference to the beginning of Ps 133 is an appeal to a transcendent authority, in order to legitimate an immanent political claim by extra-political means. This is because the benefits of harmony and unity within a political body are self-evident and could have been justified on purely secular and immanent grounds, such as reason. It is precisely this subtle combination of war against radical Islamic terrorism, the appeal to a people's unity legitimated by biblical authority and territorial claims with allusions to Zionism, which creates an ambivalence of interpretation. The Zionist subtext is likely to be picked up by Evangelicals. However, it also appeals to an anti-Islamic audience without any particular interest in religious affairs. In populist politics, the messages sent out by the populist leaders are intended to remain vague and, at the same time, they must appear to be common sense, in order to win over the widest possible audience, comprising individuals with different religious beliefs and theological convictions, including atheistic worldviews. The ambiguity of referring to religious motifs in the combination with common sense rhetoric is paradigmatic for today's populist politics, and not just in American populist politics.

In order to clarify the limitations that religious belief and theological convictions impose on populist politics, the question of what we mean by populism or populist politics needs to be addressed first.

\section{Attempts to Define Populism}

In recent years, the academic literature on the study of populism ${ }^{5}$ has rocketed, and it is impossible to give a concise overview of the study of this allegedly new phenomenon in politics. It is therefore necessary to make some methodological decisions in defining populism.

The first methodological decision concerns the choice of sources. In the following, I will concentrate on just two attempts to define populism. One dates from 1968 and the other is represented by Jan-Werner

4 The suggested commitment to a kind of Christian Zionism based on the reference to Ps 133 in Trump's "Inaugural Address" of 2017 seems to be far-fetched. In hindsight, such an interpretation, after Trump has decided to move the American Embassy to Jerusalem, which he 'officially recognized Israel's true and eternal capital', appears more plausible: See for example: "Remarks by President Trump at the Israeli American Council National Summit 2019" (Trump 2019): 'The friendship between our countries is essential to achieving a more safe, just, and peaceful world. That is why every single day since I took the Oath of Office, I have stood firmly, strongly, and proudly with the people of Israel. You know that. (Applause.) The Jewish State has never had a better friend in the White House than your President, Donald J. Trump. (Applause.) That, I can tell you. For over 20 years, every previous President promised to move the U.S. Embassy to Jerusalem. And they never acted, they never did it. They never had any intention of doing it, in my opinion. (Applause.) But unlike other politicians, I kept my promises. Two years ago this week, I officially recognized Israel's true and eternal capital, and we opened the American Embassy in Jerusalem, finally. (Applause.)' Available at: https://www.whitehouse.gov/briefings-statements/ remarks-president-trump-israeli-american-council-national-summit-2019/. Last accessed May 2020.

5 For example, Roger Eatwell and Matthew Goodwin's widely distributed short book focuses on the socio-cultural aspects of the rise of national populism as the main contemporary challenge to the moral value system inherent to liberal democratic cultures (Eatwell and Goodwin 2018). 
Müller's more recent and highly influential theory of populism, published in 2016 (Müller 2016). ${ }^{6}$ These two cross sections into the history of the study of modern populist politics will be compared with special attention to the role religion plays in the 1968 debate and Müller's definition of populism as a moralistic imagination of politics, formulated half a century later. The proposed diachronic analysis of two seminal attempts in defining populism allows us to identify essential aspects of populism. Thus, the following reconstruction of the attempts to define populism follows an approach in terms of a history of intellectual ideas rather than an evaluation of empirical sociological studies of populism.

Another methodological decision is of a chronological nature. The phenomenon of populism will only be analysed as a contemporary phenomenon in politics after World War II. ${ }^{7}$ The beginning of the study of contemporary populist politics coincides with the rise of neo-Marxist political philosophy in the 1960s, for good reasons.

Populist politics and 1960s neo-Marxist movements have at least two essential aspects in common. First, they both rely on a sharp distinction between the masses of the ordinary man (the people or the proletariat) which is set up against the elitist minority (bourgeoise capitalist or the wealthy political class). This division of classes is also morally connotated. The majority of the ordinary folk is considered authentic, genuine and good. Whereas, the elite is seen as being corrupt, selfish and morally evil. Some analysts of populist politics call this 'a dyadic left-wing populism', that opposes the elite to the genuine people (Arato and Cohen 2017, p. 286). ${ }^{8}$ In this respect, both neo-Marxism and contemporary populist politics are intrinsically rooted in resentment as a psycho-social mechanism. Secondly, the binary division of classes based on resentment calls for immediate action to rectify the current status quo and to get things right again. Neo-Marxism and contemporary populist politics are both backward looking (to get things right again) and forward looking (taking immediate/revolutionary action for a better future society).

\subsection{How to Define Populism (1967)}

Between 19th and 21st May 1967, a conference called 'To define populism' was held at the London School of Economics. Among the forty-four listed participants, with an overwhelming male dominance, ${ }^{9}$ were Sir Isaiah Berlin, Richard Hofstadter, Donald MacRae, Leonard Schapiro, Hugh Seton-Watson, Alaine Touraine, Peter Wiles and Peter Worsley, just to name a few, illustrating the academic excellence assembled. The findings of this early engagement with populism have been documented in two versions. The proceedings of the conference itself were published in the journal Government and Opposition (1968) (Berlin et al. 1968) and a year later as an extended edited book. The book Populism: Its Meaning and National Characteristics (1969) (Ionescu and Gellner 1969) was edited by Ghita Ionescu, who acted as rapporteur of the conference and later became a professor of government at the University of Manchester, and Ernest Gellner, at that time a professor of philosophy, logic and scientific method at the London School of Economics.

These two documentations of the findings and early discussion of the meaning of populism vary significantly. The edited book intends to present a concise evaluation of the phenomenon of populism, but the documentation of the proceedings of the conference by Ionescu allows a close look at the dynamics and political discrepancies that came to the fore during the conference. As one reviewer of

6 The essay is an extended elaboration of Müller's Viennese lecture series IWM-Vorlesungen zu den Wissenschaften vom Menschen 2014. The essay has been translated into several languages and has been widely received. Within the year of publication, the original essay in German reached its 5 th edition.

7 Earlier discussions of populist politics and modern democracy, as for example, in Max Weber' essay Parlamentarismus und Demokratie of 1917/18, will not be considered (Weber 1980, pp. 857-68).

8 Dyadic left-wing populism is opposed to a triadic right-wing populism. Arato and Cohen, following J. Judas note that right wing populism 'not only champions the people vs. the elites but also defends them horizontally against a third group, deemed an alien part of the population which the establishment is accused of coddling at the expense of the rightful an authentic people.' (p. 286).

9 Ellen de Kadt is the only female participant listed. 
the edited book wrote: 'Unfortunately the book does not reproduce the excellent conference discussion' (De Kadt 1970, p. 138) and therefore suggests that the reader should refer to the documentation of the conference proceedings published in the journal Government and Opposition instead of the book. One of the key advantages of the published conference proceedings of 1968 is that Ionescu, the rapporteur, has clustered the conference contributions around three systematically organised key topics, irrespective of the chronological order in which these contributions were made. The three identified topics are: I. types of populism, II. essential aspects, and III. towards a definition (Berlin et al. 1968, p. 138).

Ionescu's systematic organisation of the debate is less evident in the edited book and the following summative analysis of this early discussion of the meaning and characteristics of populism refers to the conference proceedings rather than the edited book.

In the first section, types of populism, the rapporteur documents the global scope of the conference in its attempt to clarify the meaning and significance of populism. Five different geographically distinct populist phenomena are discussed: a historical debate of Russian populism, American populism, then, contemporary populist politics in Latin America, Africa and Asia (mainly in India and Maoism in China). Surprisingly, a discussion of populism in European democratic societies is missing entirely. It is also remarkable that the portrayals of populism in 19th century Russia and early 20th century America are of a historical nature, whereas populism as a political phenomenon in Latin America, Africa and Asia were seen and treated as contemporary issues.

Religion has been acknowledged by various presenters as being an important factor in the formation of populism. Leonard Shapiro, for example, noted that Russian populists (narodniks) of the 19th century and their conception of people (narod) 'grew up on the soil of Orthodoxy' (Berlin et al. 1968, p. 142). Peter Wiles and Peter Worsley stated that some distinct populist movements in America were inspired by 'biblical knowledge' in their anti-establishment attitudes and that North American populist leaders 'were drawn largely from the ranks of preachers, Methodists and so on' (Berlin et al. 1968 , p. 144). References to religion are marginal and the theme of religion and populism was not explicitly discussed in any of the keynote papers.

In the second cluster of topics, essential aspects, the reader of the conference proceedings senses the experts' difficulties of finding a consensus on how to define populism and to agree on a working definition. The attempt to define 'those specific aspects of populism which could provide the basis for a conceptual examination', writes the rapporteur (Berlin et al. 1968, p. 155), almost failed. A consensus in this intermediate stage of the conference was impossible to reach. Most of the discussion revolved around questions such as whether Marxism, Maoism, Socialism or Anarchism should be seen as populist movements, or to what extent populism depends on nationalism and whether populism should be treated as an independent ideology. Nevertheless, the attempts to identify those specific aspects of populism to provide a basis for a systematic conceptual examination of populism foregrounded key elements of populist politics which are still relevant today and will resurface in Müller's theory of populism defined as moralistic imagination of politics. These key aspects are reflected in the last part of the conference report, under the title, towards a definition. The vivid discussion documented in the section essential aspects also shows an increased interest in the role religion has played and can play in populism. Hugh Seton Watson remarked that the 'idolization and worship of the people' without which there could be no populism and asked the question whether 'Idolization of the people might be a sort of deviation from that element in Christianity which stressed the humble and the meek at all costs' (Berlin et al. 1968, p. 156). Without mentioning Nietzsche's legacy, he continues: 'In such a conception squalor and misery were virtuous in themselves. Maybe this went back through Christianity to an earlier Judaic tradition' (Berlin et al. 1968, p. 156). Peter Wiles thought 'part of the definition was that populism could not exist without religion, at least without acceptance of religion [ ... ]' (Berlin et al. 1968, p. 159).

So far, religion has been recognised as an important, but not necessarily defining aspect of populism. Furthermore, religion has been noticed in its positive function, that is religion's potential 
to underpin populist ideas by providing a source of legitimacy based on a notion of transcendence, similar to Trump's reference to the Bible and Ps 133, as discussed above. Religion is also recognised as a reservoir for rhetorical devices, metaphors and symbols, which can be exploited effectively for the populists' political agenda. A distinction between religion and theology is missing, as well as a discussion of the limiting and prohibitive nature of religion with regards to populist politics.

The last section towards a definition shows some signs of fatigue by the participants. The rapporteur Ionescu admits self-reflectively: 'Ghita Ionescu was still not sure, at the end of the conference, whether a definition would emerge from it. As the rapporteur, he thought that a definition was not essential. The discussion, like the play, had been the thing' (Berlin et al. 1968, p. 168). Donald MacRae made the first attempt to overcome the deadlock. He suggested a list of core aspects of populism. He considered populism as an ideology, and 'its propaganda' contains fourteen universal elements. Among them are:

'1. The idealization of a Volk, and it had to be a particular one, not the idealization of the people, but of a people.

2. Primitivism, meaning that the future was to be an improved archaic past.

6. Xenophobia.

10. Belief in conspiracy. [ ... ]

11. Apocalyptic dreams. These might involve the dreams of a particular populist redeemer, a populist hero. [ ... ]

12. Belief in spontaneity. The whole mass was a spontaneous mass of untutored and immediate virtue.

13. An affiliation with religion. [... ]

14. Anti-elitist but inspired often by an elite, and prepared to use, an elite in the destruction of an elitist situation'

(Berlin et al. 1968, pp. 172-73).

Isaiah Berlin, who chaired the last session, seconds MacRae's outline of the key characteristics of populism in many respects, and delivers an eloquent summative paper trying to establish a consensus. He stresses the importance of the concept of the people (Volk, Gemeinschaft) which populists claim needs to be morally regenerated and their glory restored, after a period of a hostile infiltration that led to its spiritual degeneration. 'There must have been a spiritual fall somewhere', he said. There must be someone to blame for this fall and Berlin continues: 'Who the enemies are, we do not specify. That will depend on the specific situation' (Berlin et al. 1968, p. 174). Here, Berlin directly addresses the issue of xenophobia, raised by MacRae, and suggests a kind of scapegoat mechanism inherent to all forms of populist politics. ${ }^{10}$ More explicitly, he asks: 'By whom have they been damaged? They have been damaged by an elite, either economic, political or racial, some kind of secret or open enemy-capitalists, Jews, bureaucrats etc. Whoever the enemy is, foreign or native, ethnic or social, does not much matter' (Berlin et al. 1968, p. 175). Finally, he mentions one last general characteristic of populism. Populism 'occurs in societies standing on the edge of modernization - that is to say, threatened by it, or hoping for it $[\ldots]$ in either case uneasily aware of the fact that they cannot stand still [ ... ]' (Berlin et al. 1968, p. 175). These societies are confronted with two options: they either 'in some way catch up' with modernization, its economic and capitalist implications, or they 'create some kind of walls with which to resist them'(Berlin et al. 1968, p. 175).

10 For the relation between Rene Girard's theory of the scapegoat mechanism and populism, see (Palaver 2019). Stefano Tomelleri has recently published a sociological approach to ressentiment from the perspective of Girard's mimetic theory and analyses the scapegoat mechanism with reference to Friedrich Nietzsche's concept of ressentiment and Max Scheler, illustrated by a close examination of the Italian populist party Lega Nord (Tomelleri 2015). 
Isaiah Berlin makes an important point here. From an economic, cultural and educational perspective, populism is portrayed as a style of politics which draws its strengths from the appeal to the underprivileged masses, who are classified by the intellectual elite as the 'losers of modernity'. The 'losers of modernity' argument is another formulation of psycho-social resentment thesis evidenced by empirical data.

Berlin's evaluation of religion and populism is short. Contrary to MacRae, Berlin does not think that populism's affiliation with religion is essential, but might be true for some specific populist groups, such as Russian populism in the 19th century and its engagement with Orthodoxy.

Overall, the conference 'To define populism' of 1967 at the LSE has provided the conceptional basis for further research into the contemporary phenomenon of populist politics after the Second World War. Due to its attempt to conceive populism from a global perspective, a consensus on a universal definition of populism failed. It is almost an irony that the final definition of populism, as reported by Ionescu, was formulated by George Hall from the Foreign Office and not by one of the academic experts. ${ }^{11}$

Despite this failure of providing a consistent and persuasive definition of populism, the 1967 debate has identified key aspects of populist politics which are still referred to in the study of populism today, such as Jan-Werner Müller's discussion of populist politics.

\subsection{Müller's Theory of Populism: Populism as a Moralistic Imagination of Politics (2016)}

One of the most recent attempts to define populism and to analyse who should be considered a populist was made by Jan-Werner Müller (Müller 2015). ${ }^{12}$ His conception of populism goes beyond a purely descriptive analysis of the phenomenon and provides a consistent theory. Müller's theory of populism substantially augments the achievements of the 1967 conference. His theory of populism is similarly universal in its design, but is more persuasive, due to its clear and simple definition of populism as a moralistic imagination of politics. It also provides arguments based on empirical studies. Müller's theory of populism plausibly argues why certain core aspects of populist politics, as listed by MacRae, for example, ${ }^{13}$ should not be considered essential to the definition of populism.

Thus, Müller's definition of populism sharpens the focus on what populism essentially is. His theory of populism starts with a list of exclusions of explanatory reasons for the rise and success of populist politics.

For Müller, some common assumptions about populism need to be refuted. His main criticism of the traditional views of populism concerns the 'losers of modernity thesis', coupled with a psychological classification of populist voters. According to the losers of the modernity thesis, populism is a phenomenon that occurs among those people who are economically, geographically and socially disadvantaged. Populism has often been associated with a specific class, the petty bourgeoisie, which have not been able to catch up with the rapid development in modernity. 'This approach', Müller writes, 'usually comes with an additional set of criteria drawn from social psychology: those espousing populist claims publicly and, in particular, those casting ballots for populist parties, are said to be driven by "fears" (of modernization, globalization, etc.) or feelings of "anger," "frustration," and "resentment"' (Müller 2016, p. 12). His counterargument is based on the lack of evidence for

11 This final very diplomatic attempt to define populism by G. Hall was agreed to probably be the 'best general definition of the populist movements. [ ... ] But everyone also agreed that the subject was much too vast merely to be contained in one definition [... ].' George Hall's definition said: 'Populist movements are movements aimed at power for the benefit of the people as a whole which result from the reaction of those, usually intellectuals, alienated from the existing power structure, to the stresses of rapid economic, social, cultural or political change. These movements are characterized by a belief in a return to, or adaptation of, more simple and traditional forms and values emanating from the people, particularly the more archaic sections of the people who are taken to be repository of virtue' (Berlin et al. 1968, p. 179).

12 English translations are taken from Müller (2016). The English edition differs from the German edition, but Müller's theory of populism remains identical in its core arguments (Müller 2017).

13 Müller briefly refers to the 1967 conference 'To define populism' (Müller 2015, p. 15). 
such a hypothesis. The losers of modernity thesis simply does not correspond with economic facts, because populism is also successful among the economically and socially successful urban classes. The psychological argument, based on the assumption that resentment is inherent to populist mass mobilisation, is misleading and misses the point. Resentment, Müller argues, can be found in any style of politics, and can therefore not explain the rise of populism today. Closely related to the idea of resentment, as a motor of populist politics, is the idea that populism is exclusively based on the antagonism and struggle between a privileged, corrupt elite and an authentic, genuine people. In fact, Müller notes, anti-elitism is a necessary, but not sufficient, condition to qualify as a populist.

What, then, is populism? What is the logic of populist politics? In an earlier short essay, Müller presents his definition of populism:

Populism, I suggest, is a particular moralistic imagination of politics, a way of perceiving the political world which places in opposition a morally pure and fully unified people against small minorities, elites in particular, who are placed outside the authentic people. In other words, 'the people' is not really what it appears to be, prima facie, in its empirical entirety, or what might seem, on the basis of voting or other political procedures, to be the 'popular will'. Rather, as the important theorist of modern democracy Claude Lefort once put it, for populists, first 'the people must be extracted from within the people'. The flipside is that populists claim that they-and only they-properly represent the authentic, proper, and morally pure people. This is the core claim of populists. Political actors not committed to this claim, according to my understanding, are simply not populists.

(Müller 2015, p. 83)

Müller re-formulates his definition almost identically in the essay 'What is Populism':

Populism, I suggest, is a particular moralistic imagination of politics, a way of perceiving the political world that sets a morally pure and fully unified-but, I shall argue, ultimately fictional—people against elites who are deemed corrupt or in some other way morally inferior. It is a necessary but not a sufficient condition to be critical of elites in order to qualify as a populist. Otherwise, anyone criticizing the powerful and the status quo in any country would by definition be a populist. In addition to being anti-elitist, populists are always anti-pluralist: populists claim that they, and only they, represent the people.

(Müller 2016, pp. 19-20)

The latter definition of populism is also supported by the reference to Claude Lefort, as mentioned above. Therefore, the idea of an imagined people extracted from the empirical people proves to be crucial to Müller's theory of populism as a moralistic imagination of politics. ${ }^{14}$

It is the struggle between the imagination of a morally pure, authentic and genuine people extracted from the empirical people, which is juxtaposed to the inauthentic, privileged and morally corrupt elite. The populist leader claims to represent the will of the true people against any forms of an elitist political representation which only represents and pursues their selfish interests and not the 'real' interest of the 'real people'. It is only the populist leader who dares to say what the true people really think and want. Any disagreement with the populists' representation of the alleged will of such an imagined genuine people is, per se, a betrayal of the real people, or is articulated from someone who does not really belong to the authentic people. This is precisely the reason why for Müller populist politics is essentially anti-pluralist. It cannot allow opposition nor can it tolerate alternative views, because they must be, by definition, against the will of the genuine people.

This can be illustrated once again by Donald Trump's inaugural address as a textbook example of populism:

14 One of the first attempts to formulate a general theory of populism, citing Claude Lefort in the title of the essay, is documented in Müller (2014). 
For too long, a small group in our nation's Capital has reaped the rewards of government while the people have borne the cost.

Washington flourished-but the people did not share in its wealth.

Politicians prospered-but the jobs left, and the factories closed.

The establishment protected itself, but not the citizens of our country.

Their victories have not been your victories; their triumphs have not been your triumphs; and while they celebrated in our nation's Capital, there was little to celebrate for struggling families all across our land.

(Trump 2017)

The roles are clearly defined here. On the one hand, there is an elitist group of people in Washington who are morally corrupt and selfish, and, on the other, there are the real people of America. It is the real Americans who are suffering while the 'establishment protected itself, but not the citizens of our country'. 'The Unites States of America, is your country', Trump reaffirms to his audience, which, as representatives of the true people, 'came by the tens of millions to become part of a historic movement the likes of which has never seen before'. The same mechanism of resentment is then played out internationally, when Trump famously declares: 'From this moment on, it's going to be America First' (Trump 2017).

More passages taken from Trump's inaugural address could be taken to illustrate the plausibility of Müller's theory of populism. However, it would be misleading to reduce Müller's influential essay 'What is Populism' to just a theoretical conceptualisation of the phenomenon of the global rise of populist politics. In his essay, he also demonstrates which power techniques are applied by populist leaders to secure their dominion (Müller 2015, pp. 70-74). Müller's anatomy of populist power techniques is followed by a discussion of how one should deal with populism today without transgressing the moral and political boundaries set by a democratic culture (Müller 2015, pp. 91-128). ${ }^{15}$

As a result of the suggested cross section analysis of the debate on populism with regards to religion, one can conclude:

Müller's theory of populism covers most of the descriptive characteristics of populism identified in the 1967 debate and focuses the discussion by rejection of the 'losers of modernity thesis' and by raising doubts about a purely psychological explanation of the phenomenon based on the socio-psychological mechanism of resentment.

In fact, resentment, as a psycho-social mechanism, reappears in Müller's theory of populism in his portrayal of the logic of populist politics as a struggle between a morally qualified, imagined pure people set up against an elite or any other morally corrupt (or even ethnically unqualified) group of people who form an opposition to the populist's claim to represent the true will of the true people. It can be questioned whether Müller's theory of populism dismisses the Nietzschean concept of resentment as socio-psychological motor of populist politics too quickly. Nietzsche identified resentment with a specific class, that is the mob, whose moral categories follow the grammar of good versus evil. Surely, it is Nietzsche's apodictic disavowal of resentment among the superior class that weakens his argument. There is no reason and no empirical evidence why the upper class and their moral categories of good and bad should not be open to the feeling of resentment. ${ }^{16}$

Anti-elitism as such, Müller repeatedly insists, is a necessary but not sufficient condition to qualify a political leader as populist not to define populist ideology. The two other ingredients for populism are its antipluralist nature and their leader's absolutist claim to represent the totality of the authentic

15 The essay is concluded by ten summarising, and at the same time explorative, theses on the future of representative democracy and the challenge populism poses to it.

16 It can be argued that resentment is a psycho-social mechanism independent of social class (Hoelzl 2017, pp. 187-98). 
people which cannot tolerate dissent from their populist course of action. ${ }^{17}$ The most significant feature of Müller's theory is that it draws attention to the antipluralist nature of all populist politics.

Interestingly, Müller does not regard religion as a factor which plays any essential role in the conceptualization of modern populist politics, whereas religion was still an issue at the 1967 conference.

\section{Religious Beliefs and Theological Convictions as an Antidote to Populist Politics}

To understand the critical function of religion for populist discourse, one needs to ask to what extent the use of religion is detrimental, or even toxic, to the populists' moral imagination of politics.

\subsection{Secular Pluralism and the New Visibility of Religion Thesis}

Paradoxically, it is due to secularisation that the reference to religion in populist politics is met with some caution. One of the results of secularisation is that a uniform religious world view of the empirical people can no longer be assumed. A populist leader's appeal to religious authority, like Trump's reference to the Bible and Psalm 133 in particular, might turn out to be divisive, and therefore is counterproductive for the imagination of a united people, which is essential to all populist politics. Secularism itself is pluralist and therefore toxic to any populist vision of one people united by one uncontested faith, or systematic system of belief. It is almost impossible to take a commonly shared belief system for granted. This is at least true for predominantly secularised Western society, shaped by the Judeo-Christian tradition. The pluralism of religious beliefs did not start with the secularisation of Western societies. It is the hallmark of all religions that they represent a plurality of differing theological truth claims within its own empirical people. The red line between orthodoxy and heresy is, and has indeed always been, very thin. Even the Catholic Church, which is often portrayed as a monolithic block in its doctrinal teachings, shows a great internal variety of theological truth claims, and the history of the Christian Church as a whole can be read as a history of permanent negotiation, violent demarcation and attempts to find a consensus on doctrinal matters of true belief. Every religious institution seeks to reconcile the pluralism of truth claims inherent to theology in a more or less peaceful way, and to integrate all those doctrinal differences in a unified dogmatic system of belief for the sake of political unity. ${ }^{18}$

Thus, secularisation is only a catalyst in the rapid increase of the pluralism of theological truth claims, resulting in a plurality of individual and a new visibility of syncretistic religious world views, which are not always easy to reconcile with the traditional systems of belief represented by institutionalised religious associations.

One of the implications of the new visibility of religion thesis (Hoelzl and Ward 2008a, pp. 1-9) is that religion is becoming more visible but in different forms. Contrary to the predicted re-emergence of religion in the 21st century after a period of secularisation, the new visibility of religion thesis stresses the fact that the new visibility of religious phenomena today have changed our understanding of religion, whereas the re-emergence of religion theory claims a resurgence and recovery of religion as we

17 A more recent discussion among social scientists on defining key features of populism can be found in (Bonikowski et al. 2018). As a summary, the authors write: 'All contributors see populism as thin-centred and agree on many of its core features: anti-pluralism, anti-elitism and the juxtaposition of a virtuous people against elites and fifth columns. With regard to the relationship between populism and democracy, all contributors agree that populism can be hostile to liberal democracy' (p. 2). Religion is only mentioned twice, without further analysis of the relation between religion and populism (pp. 8; 19).

18 The Second Vatican Council, in its document on the Church (Lumen Gentium, LG 14, note 26), notably recognises this with Augustine. The question at stake is who is really in the church, as an institution which can exclusively grant salvation, and who is not. In other words, who is really a true believer and who is not. The remarkable conclusion is that empirical membership of the church is not a guarantee for salvation and even those who are empirically 'outside the Church' might, in their heart, belong to the Church (Rahner and Vorgrimmler 1993, pp. 139-40). It is tempting to analyse the Catholic teachings of the twofold nature of the Church, its visible and invisible body, its human and divine elements (Lumen Gentium, $L G 8)$, to the populist construction of an empirical and imagined people. A crucial difference between the theological understanding of the invisible church and the populist imagination of a morally pure and unified people is that the theological understanding of community of believers also includes the past, present and future members of the body of the Church. Therefore, it cannot be identified with an actual empirical people, like in nationalist populism. 
know it, in the sense that re-emergence is understood literally as the recovery of religious institutions and theological convictions. However, there is no evidence for such a claim, as Norris and Inglehart have convincingly shown (Norris and Inglehart [2004] 2011). Secularisation, understood as the decline of religion's impact on the public sphere, and the importance of highly institutionalised religion in particular, is an ongoing process. The advantage of the new visibility of religion thesis is that it does not deny the empirical facts of ongoing secularisation, but it draws attention to the new forms of religion that become increasingly visible today. With this new visibility of religion comes a new pluralism of religious phenomena. For this reason alone, it is dangerous for any populist politician to assume a uniform and monolithic religious belief system adhered to by the people addressed in populist politics. Even the assumption of an imagination of the true and authentic, pure people is difficult to reconcile with a single uncontested and commonly shared religious belief. Secularisation's pluralism of belief is one limitation of the use religion in populist politics in Western democratic and secularised societies.

The problem of religious pluralism of beliefs and the consolidation of a united political body by religious means is not a new one. It was already addressed by key-thinkers of modern political thought. Jean-Jacques Rousseau, in his proposal of 'civil religion', and Alexis de Tocqueville's sociological analysis of 'republican religion' in America are the most prominent and earliest examples to illustrate this.

\subsection{Civil Religion, Civil Society and Theological Pluralism}

The political proposal for civil religion that unites the political body of a people is a child of deism, inherent to the era of the Enlightenment. Rousseau's concept of civil religion is an answer to the twofold question of how religion can contribute to the imagination of a uniform people and what kind of religion is needed to guarantee the unity of an empirical people.

The chapter on civil religion was not included in the first edition of 1760 (Hoelzl and Ward 2006, p. 123). In the second edition of Jean-Jacques Rousseau's Contract Social of 1762, he defines the requirements of the proposed civil religion: 'The dogmas of civil religion ought to be few, simple and exactly worded, without explanation or commentary' (Rousseau 1923, p. 121). Rousseau's proposed civil religion is designed to eliminate any possible doctrinal dispute. Its dogmas must be few and must not rely on any external authority for explanation. The shared belief system must be self-evident and simple. There is no need for external guidance, such as the clergy, in interpreting one's religious belief. Civil religion is a natural religion and its theological truth claims do not transcend the limits set by reason. Therefore, civil religion operates on a minimum of theology, in order to avoid any theological sectarianism. ${ }^{19}$ Its purpose is to unite the empirical people and to sustain the imagination of an undivided authentic people, on which, according to Müller, all populist politics depends. Rousseau's civil religion is in indeed a form of political theology designed to use religious sentiments as a means for political ends. ${ }^{20}$ The ultimate end of every political theology is the idea of a unified people and the legitimation of sovereignty, or sovereign leader by recourse to a transcendent source of authority. The question is how much diversity, pluralism of convictions and divergence political theology allows in its moralistic imagination of politics.

19 The minimal theology of civil religion is defined by Rousseau's list of dogmas. The citizen and follower of civil religion believes in: 'The existence of a mighty, intelligent and beneficent divinity, possessed of foresight and providence, the life to come, the happiness of the just, the punishment of the wicked, the sanctity of the social contract and the laws: these are its [civil religion's] positive dogmas. Its negative dogma I confine to one, intolerance, which is part of the cults we have rejected' (Rousseau 1923, p. 122).

20 Robert Bellah successfully re-introduced, in the late 1960s, Rousseau's concept of civil religion to characterise religion and politics in America (Bellah 1967, pp. 1-21). Bellah's portrayal of American civil religion must be regarded as a political theology of political unity operating on a minimal theological consensus, as expressed in the formula 'God bless America'. Every true American should be able to agree with this formula, because the theological and doctrinal content of what or who God refers to remains ambivalent and can therefore host a variety of different beliefs in a vague notion of an almighty, transcendent authority. 
Andrew Arato and Jean L. Cohen have raised this question with respect to the dangers that the amalgamation of populism and politicised religion poses for civil society and its fundamental values of plurality, publicity, privacy and legality (Arato and Cohen 2017, pp. 283-95). In their essay, the authors argue that the logic of populism and of politicized religion is antithetical to the underlying principles of civil society and, ultimately, to democracy itself. '[ ... ] both populist movements and political religion are in but not necessarily of civil society. On their own, but especially when they merge or ally, populist and politicized religious identity politics pose serious challenges to constitutional democracy' (Arato and Cohen 2017, p. 283). Arato and Cohen's warnings of the dangers to civil society are formulated in the legacy of Hannah Arendt's advocacy of pluralism and Jürgen Habermas' defence of the public sphere. Both authors concur with Müller's definition of populism in its key essential features, that is, the anti-pluralist nature of populist politics and the imagination of a pure, authentic and morally superior people extracted from an empirical people. Arato and Cohen's argument is convincing, but they seem to use the term 'politicized religion' and 'political theology' interchangeably. For them, political theology can be effectively used by populist movements. Because, 'populism's predilection for a unitary, substantive conception of the people, its friend/enemy logic, its effort to frame that part as a whole (pars pro toto) with moral superiority, its affinity with symbolic representation and the logic of embodiment, and incarnation, entails a modern form of political theology' (Arato and Cohen 2017, p. 288).

'But', as Arato and Cohen emphasise, 'political theology is not religion' (Arato and Cohen 2017, p. 289). Political theology and politicised religion are corrupted versions of true belief: 'Yes, populists hijack religion and turn it into a useful tool for their friend/enemy identity politics' (Arato and Cohen 2017, p. 290), they write. Interestingly, Arato and Cohen's argument of political theology as a perversion of religious belief is not based on theological grounds. They do not mention the controversy between Eric Peterson and Carl Schmitt over the theological impossibility of any political theology because of the doctrine of Trinity and Incarnation in Christian monotheism at all (Geréby 2008; Hoelzl and Ward 2008b). Their argument focuses on the different concepts of sovereignty at stake in populist politics and institutionlaised associations of religious belief (e.g., churches).

Arato and Cohen argue:

'Populism is in tension with monotheistic, salvation religions [ ... ] they refer to very different and incompatible sovereigns: the sovereign people and their very worldly authority in the case of populism, vs. a transcendent sovereign deity, an otherworldly lawgiver whose earthly high priests are religious figures, not politicians. [ ... ] The confiscation of religion by populists and attempts to use it to sanctify the nation, the people, or the leader, and to conscript it into the service of the political friend/enemy logic is, from the religious point of view, blasphemy (Arato and Cohen 2017, p. 289)'.$^{21}$

The example to illustrate their argument is the moral dilemma evangelicals faced in their support of Donald Trump. On the one hand, Christian evangelicals sympathised with his morally conservative agenda, on the other, they were very sceptical of the authenticity of his proclaimed commitment to faith.

The interesting point made by Arato and Cohen is the limitation that true belief and true religion impose on populist politics. Theological truth claims ultimately refer to a transcendent source of sovereign authority and any attempts to sacralise a mundane political entity, whether it is the populist leader or the authentic people as such, 'is tantamount to idolatry' (Arato and Cohen 2017, p. 290).

This is the second limitation that religion poses to populist politics: any identification of a mundane source of sovereign authority with divine and therefore transcendent and ultimately sovereign authority must be rejected as a blasphemy by true believers. For the true believer, no temporal authority can be regarded as the absolute sovereign.

21 My italics. 


\subsection{Beyond Resentment: Religion's Anti-Populist Moral Imperative}

The third and last limitation of religious beliefs, as well as institutionalised religious associations, pose a normative, moral issue to populist politics. Any universal religion of salvation is detrimental to populist politics for at least two reasons. The first, moral hindrance of a purely populist instrumentalization of religion is the theological doctrine of the sinfulness of all humans. A populist construction of a morally pure people must seem dubious to the religious believer who is aware of the sinfulness of human nature. The political imagination of a morally perfect, immaculate community that is juxtaposed to a morally corrupt group of others can only resonate with religious groups which operate on a strict distinction between the believer and the non-believer; the chosen people set up against the savage others.

Finally, in all religions' moral teachings, the solidarity with the poor and the needy is expressed, which transgresses political and national boundaries. The moral imperative to charity ${ }^{22}$ is detrimental to populist politics based on the logic of a clearly defined friend/enemy distinction. In other words, the moral imperative to charity and charitable works does not allow resentment.

Of course, these two normative limitations are of a moral and imperative nature and do not necessarily correspond, and often have not corresponded, to the actual reality of the politicisation of religion or the sacralisation of politics.

\section{Conclusions}

These three limitations of populist politics set by religious belief and theological convictions exemplify the critical and anti-populist potential of religion. The list of incompatibilities of religion and theology with populist politics does not claim to be comprehensive. On an individual level, for example, there is a crucial difference between a populist leader and a charismatic religious leader. The latter, according to Max Weber's classic definition of charismatic leadership, must appear to have withdrawn from this world and the burden of everyday life. Direct followers of the charismatic leader must be equally remote from any worldly affairs (Weber 1980, p. 656). However, a populist leader seeks to demonstrate exactly the opposite. A populist leader is part of this world and everyday life. He or she must appear to be like the common folk, because he or she does not belong to the morally corrupt elite or the class of inauthentic people. This is one reason why immediate communication via social media is vital in populist politics today. Religious charismatic leaders, on the other hand, benefit from an erratic aura and their messages convey an aroma of arcane secrecy.

There is a tension between religion and populism, despite their most obvious forms of cooperation and potential of amalgamation. The plurality of religious beliefs, institutionalised religious associations and their moral imperative to charity, as well as theological convictions, impose hinderances to the instrumentalization of one party by the other. If we accept that populist politics is currently the most serious threat to a democratic culture, ${ }^{23}$ then the thesis of a new visibility of religion needs to be reconsidered in terms of its political impact. Given the new visibility of religion, I would like to suggest that Ernst-Wolfgang Böckenförde's paradoxon ${ }^{24}$ can be reformulated to describe the incompatibility of religious belief and theological conviction with contemporary populist politics. According to Böckenförde, the 'liberal secularized state lives by prerequisites which it cannot guarantee itself'. Such a state has to take 'this great risk for the sake of liberty', (Böckenförde 1992, p. 112). ${ }^{25}$ The reformulation of Böckenförde's paradoxon suggested here is: secularised, liberal, democratic

22 This has been understood, for example, as 'option for the poor' in liberation theology (Kruip 2017).

23 Müller quotes Herman Van Rompuy, then president of the European Council, who said in 2010: 'Die große Gefahr ist der Populismus [The great danger is populism]' (Müller 2017, p. 9). See also note 2.

24 Böckenförde's paradoxon was first formulated in 1967, published in Ebracher Studien in a Festschrift for Ernst Forsthoff under the title: 'Die Entstehung des Staates als Vorgang der Säkularisation [The creation of the state as a result of secularisation]' (Böckenförde 1992, p. 381).

25 My translation. For a detailed discussion of Böckenförde's paradoxon see: Schmidt and Wedell (2002). 
cultures have to take to risk to rely on those religious residues, which could provide an antidote to an exclusivist, anti-pluralist populist politics, dominated by a populist leader who claims to solely represent the will of the true, morally pure and authentic people.

Funding: This research received no external funding.

Conflicts of Interest: The author declares no conflicts of interest.

\section{References}

Arato, Andrew, and Jean L. Cohen. 2017. Civil society, populism and religion. Constellations 24: 283-95. [CrossRef] Bellah, Robert N. 1967. Civil Religion in America. Daedalus 96: 1-21.

Berlin, Isaiah, Richard Hofstatder, Donald MacRae, Leonard Schapiro, Hugh Seton-Watson, Alain Touraine, F. Venturi, Andrzej Walicki, and Peter Worsley. 1968. To define populism. Government and Opposition 3: 137-79.

Böckenförde, Ernst-Wolfgang. 1992. Staat, Gesellschaft, Freiheit. Frankfurt: Suhrkamp.

Bonikowski, Bart, Daphne Halikiopoulou, Eric Kaufmann, and Matthijs Rooduijn. 2018. Populism and nationalism in a comparative perspective: A scholarly exchange. Nations and Nationalism 25: 58-81. [CrossRef]

Calvin University. n.d. Populists or Internationalists? Evangelical Responses to Globalization. Available online: https://calvin.edu/centers-institutes/henry-institute/projects/populists-or-internationalists/ (accessed on 30 May 2020).

De Kadt, Emanuel. 1970. Review. International Affairs 46: 138-39. [CrossRef]

Eatwell, Roger, and Matthew Goodwin. 2018. National Populism: The Rise against Liberal Democracy. London: Pelican.

Geréby, György. 2008. Political Theology versus Theological Politics: Erik Peterson and Carl Schmitt. New German Critique, 7-33.

Guth, James. 2016. Are White Evangelicals Populists? The view from the 2016 American National Election Study. Review of Faith and International Affairs 17: 20-35. [CrossRef]

Hoelzl, Michael. 2017. Die normative Kraft des Kontrafaktischen. Populistische Positionen zwischen Ideal und Lüge. In Christentum und Populismus: Klare Fronten? Edited by Walter Lesch. Freiburg: Herder, pp. 187-98.

Hoelzl, Michael. 2020. Dispositives of Political Theology. Analyzing non-discursive elements of the Josephinian dispositive of pastoral power. In Past and Present of Political Theology. Edited by Dennis Vanden Auweele and Miklos Vassányi. London: Routledge, pp. 154-75.

Hoelzl, Michael, and Graham Ward, eds. 2006. Religion and Political Thought. London: Continuum.

Hoelzl, Michael, and Graham Ward, eds. 2008a. The New Visibility of Religion. London: Continuum, pp. 1-9.

Hoelzl, Michael, and Graham Ward. 2008b. Editor's Introduction. In Carl Schmitt. Political Theology II. The Myth of the Closure of Any Political Theology. Cambridge: Polity, pp. 1-30.

Ionescu, Ghita, and Ernest Gellner, eds. 1969. Populism: Its Meaning and National Characteristics. London: Leidenfeld \& Nicolson.

Kruip, Gerhard. 2017. "Volk" als kritischer Topos der Theologie. In Christentum und Populismus: Klare Fronten? Edited by Walter Lesch. Freiburg: Herder, pp. 38-48.

Lesch, Walter, ed. 2017. Christentum und Populismus: Klare Fronten? Freiburg: Herder.

Marzouki, Nadia, Duncan McDonnell, and Oliver Roy, eds. 2016. Saving the People: How Populists Hijack Religion. New York: Oxford University Press.

Müller, Jan-Werner. 2014. "The People must be extracted from the People". Reflections on Populism. Constellations 21: 483-93. [CrossRef]

Müller, Jan-Werner. 2015. Parsing populism: Who is and who is not a populist these days? Juncture 22: 80-89. [CrossRef]

Müller, Jan-Werner. 2016. What Is Populism? Philadelphia: University of Pennsylvania Press.

Müller, Jan-Werner. 2017. Was Is Populismus? Berlin: Suhrkamp.

Norris, Pipa, and Ronald Inglehart. 2011. Sacred and Secular. Religion and Politics Worldwide. Cambridge: Cambridge University Press. First published 2004.

Norris, Pipa, and Ronald Inglehart. 2019. Cultural Backlash: Trump, Brexit and Authoritarian Populism. Cambridge: Cambridge University Press. 
Palaver, Wolfgang. 2019. Populism and religion: On the politics of fear. Dialog 58: 22-29. [CrossRef]

Rahner, Karl, and Herbert Vorgrimmler. 1993. Kleines Konzilskompendium. Freiburg: Herder.

Rousseau, Jean-Jacques. 1923. The Social Contract and Discourses. Translated by George Douglas Howard Cole. London: Dent.

Schmidt, Susanna, and Michael Wedell, eds. 2002. "Um der Freiheit willen ... ". Kirche und Staat im 21. Jahrhundert. Festschrift für Burkhard Reichert. Freiburg: Herder.

Tomelleri, Stefano. 2015. Ressentiment: Reflections on Mimetic Desire and Society. Breakthroughs in Mimetic Theory. East Lansing: Michigan State University Press.

Trump, Donald J. 2017. Inaugural Address. Available online: https:/www.whitehouse.gov/briefings-statements/ the-inaugural-address/ (accessed on 20 April 2020).

Trump, Donald J. 2019. Remarks by President Trump at the Israeli American Council National Summit 2019. Available online: https://www.whitehouse.gov/briefings-statements/remarks-president-trump-israeliamerican-council-national-summit-2019/ (accessed on 30 May 2020).

Weber, Max. 1980. Wirtschaft und Gesellschaft. Grundriß der verstehenden Soziologie. Tübingen: Mohr.

Whitehead, Andrew L., and Samuel L. Perry. 2020. Taking America back for God: Christian Nationalism in the United States. Oxford: Oxford University Press.

Zúquete, Jose Pedro. 2017. Populism and Religion. In Oxford Handbook of Populism. Edited by Cristobal Rovira Kaltwasser, Paul A. Taggart, Paulina Ochoa Espejo and Pierre Ostiguy. Oxford: Oxford University Press, pp. 445-66.

(C) 2020 by the author. Licensee MDPI, Basel, Switzerland. This article is an open access article distributed under the terms and conditions of the Creative Commons Attribution (CC BY) license (http://creativecommons.org/licenses/by/4.0/). 